\title{
Trees in agricultural and livestock development
}

\author{
K. F. Wiersum
}

Department of Forest Management, Agricultural University, Wageningen, Netherlands ${ }^{1}$

Key words: agroforestry, multipurpose trees, farm tree utilization, agricultural development

\section{Summary}

Until recently, neither foresters nor agriculturists have paid much attention to the presence and role of trees in tropical farming systems. During the past decade, however, it has been recognized that trees outside forests may have as important a role in sustaining the natural and human environment as forests. The importance of farm trees for agricultural and livestock development stems from their potential to produce essential tree products for people living some distance from forests, and in their ability to sustain agricultural production capacity via their functions of improving the microclimate and protecting and ameliorating the soil. Rural people have long been aware of these functions and many indigenous farming systems integrate tree cultivation with agricultural cropping and/or pasture management. Several distinctive management practices are used in those systems, and the prevalent trees are often characterized by their multipurpose functions and relatively high production capacity. Unfortunately, heavy demands for tree resources and changing rural conditions result in the overexploitation of these traditional systems. There is huge scope for programmes to stimulate the proper incorporation of compatible trees on farm and pasture lands as a means to counter this loss of rural tree resources and to help improve land husbandry practices. During recent years much experience has been gained which demonstrates the appropriateness of such strategies, and several important principles have emerged that can be applied in designing further programmes.

\section{Introduction}

It is well recognized that forests have a vital role in sustaining both the natural and human environment. Forests can help to meet the basic needs of rural people and commercial needs of industry, to improve rural incomes and to combat environmental decline. Less well recognized is the fact that these functions may not only be

\footnotetext{
1 Present address: Research Institute for Forestry and Landscape Planning 'De Dorschkamp', P.O. Box 23,6700 AA Wageningen, Netherlands.
} 
displayed by forests, but also by trees growing outside established forest areas. Until recently, neither foresters nor agriculturists have paid much attention to the presence and role on agricultural land of trees other than fruit trees or commercial crops such as rubber and oil palm. Most agronomists regarded the presence of trees in fields as competition that should be eliminated, whereas most foresters were not interested in farm trees, as they do not grow in forestlike stands and cannot be managed according to standard silvicultural concepts.

However, gradually accumulating data indicate the great importance of trees for agricultural and livestock development. Also, it is increasingly being realized that most rural people live some distance from forested lands. For these people, trees scattered over the rural landscape often have a more significant role than forests in meeting their basic requirements for energy, shelter and various forms of food. With the present rates of tropical deforestation this role can only be expected to increase in significance.

This paper will discuss the roles of trees in traditional farming systems and in agricultural development in tropical countries. In addition, the potential for stimulating rural people to grow more trees on their land will be indicated.

\section{Roles of trees in agricultural development}

Trees can have complex and diverse roles in agricultural and livestock development, either by yielding direct produce or by sustaining the production capacity (see Table 1).

In many tropical regions, trees have proved to be a more favourable crop from an energy standpoint than annual food crops, as they maintain longer photosynthetic activity and have lower energy demands in both cultivation and harvesting. The latter characteristic arises because of the relatively low nutrient demands resulting from efficient mineral cycling systems, less need for irrigation (because roots tap deep groundwater) and no need of tillage with its inherent demands of fuel, machinery and the back-up support required by mechanization (Felker \& Bandurski, 1979; Watson, 1982). These favourable characteristics are augmented by the protective role of trees stemming from their ability to conserve and ameliorate the soil and to improve the microclimate.

In recent years a rapidly growing awareness has developed about these values of trees and about the potential of agroforestry practices in which trees are deliberately incorporated on farm and grazing lands. The various roles of trees have been highlighted by different authors; for example their ability to increase total productivity of the land by permitting a supplementary or complementary use of production factors (Arnold, 1983), to contribute to crop diversification on smallholder lands (Okafor, 1977; Budowski, 1983), to produce energy needed for household utilization of agricultural produce and for heating (Ben Salam \& Van Nao, 1981; Poulsen, 1983), to assist low-input agriculture and sustained use of marginal lands (Watson, 1982; Nair, 1984), or to contribute to livestock development (Torres, 1983a).

Most of the production and service functions of farm trees have also been attrib- 
Table 1. Functions of trees in agricultural and livestock development

1. Providing tree products

1.1. Intensification of subsistence production for farm and household purposes

1.1.1. Human food (fruits, nuts, vegetables, sap)

1.1.2. Food and forage for animals (foliage, fruits)

1.1.3. Fuelwood and charcoal

1.1.4. Wood for construction and farm implements

1.1.5. Fibres and thatching material

1.1.6. Others, e.g. medicinal products

1.2. Cash crop diversification resulting in increased productivity of land and/or labour

1.2.1. Timber and other commercial wood products

1.2.2. Cash crop commodities (coconut, coffee, tea, oil palm, etc.)

1.2.3. Exudates (latex, resins, gums)

1.2.4. Others, e.g. cork, pharmaceuticals

2. Sustaining production capacity and other farm service functions

2.1. Micro-climate improvement for crops and livestock

2.1.1. Wind shelter

2.1.2. Shade, and buffering temperatures

2.2. Soil conservation

2.2.1. Control of water erosion

2.2.2. Control of wind erosion

2.3. Soil improvement

2.3.1. Efficient nutrient cycling including nitrogen fixation

2.3.2. Addition of organic matter and nutrients to topsoil

2.3.3. Improved physical and hydrological conditions

2.4. Live fences and hedges

uted to forests (e.g. FAO, 1981). However, when considering the potential of trees growing outside forest reserves, care should be taken to make a clear distinction between the functions of forests and of individual trees.

The functions of forests are not necessarily related to the forest as a stand of individual trees, but rather to more specific attributes. For instance, many environmental functions of forests are related to the entire forest as a complete and wellfunctioning ecosystem. These functions may, therefore, only be manifested to a discernible extent in a sufficient large community of trees, whereas wood, fodder and fruit are produced in individual trees, even if they are standing alone.

Furthermore, many functions of tree stands are conditional. In particular, the environmental service functions of farm trees often depend on proper management regimes. For instance, the potential benefit from growing trees in combination with annual or perennial crops so as to maintain and even enhance soil productivity has been indicated by much available evidence from widely practised land-use systems (Nair, 1984a). But, as illustrated in relation to erosion control (Wiersum, 1984a), the key to effectuating these advantages does not lie in the presence of trees themselves, but rather in good management practices, either of the trees or by the application of additional agricultural technologies. 


\section{Traditions of farm tree management}

Although the role of farm trees has only recently been appreciated by foresters, agriculturists and development planners, rural people themselves have long been involved in the conservation and cultivation of trees on agricultural land. Indeed, such forms of agroforestry are among the oldest and most widely practised land-use systems. It is increasingly being recognized that the development of integrated farm tree/crop/livestock systems should be based on a knowledge of these existing agroforestry practices (Raintree, 1983; FAO, 1985). In 1982 a global inventory of agroforestry systems was started by the International Council for Research on Agroforestry (ICRAF) in order to gather quantitative data to enable the performance of these systems to be evaluated and to assess their strengths, weaknesses and scope for further development and extension.

Already, many examples of indigenous systems of combining trees and crops (agrosilviculture) or trees and pasture (silvipastoral systems) have been published. When population densities are still relatively low and land relatively abundant, agricultural crops and trees are often managed in rotation. Many shifting cultivators actively manage trees both for productive purposes and for soil regeneration. For instance, in parts of Indonesia, farmers do not cut down tree species such as Koompassia parvifolia, Arenga saccharifera, Durio zibethinus and Parkia spp, which produce fruits or act as hiving trees for bees, or they cultivate rattan as a productive fallow crop (Pelzer, 1948; Weinstock, 1983). And in Sudan the natural fallows of Acacia senegal are stimulated to produce valuable gum arabic as well as to contribute to soil protection and regeneration (Hammer, 1982). In south Nigeria farmers actually plant arboreal species such as Acioa bateri, Anthonotha macrophylla, Alchornea condifolia or Gliricidia sepium as fallow crops (Getahun et al., 1982), while in the highlands of New Guinea Casuarina oligodon is planted in agricultural fields to rejuvenate the soil and to produce wood for fences, fuel and house construction (Clarke, 1966).

In areas where the land resources are scarcer, a more permanent combination of tree and agricultural crops may be found. For example, in West Africa over forty species of indigenous trees are preserved on farmland in densities from less than one to over 40 trees per hectare (Pullan, 1974; ORSTOM, 1980). Four species dominate much of these 'farmed parklands', i.e. Adansonia digitata, Butyrospermum paradoxum, Parkia clappertonia and Acacia albida. The first three species produce important items for the diet of the local people, while Acacia is widely cultivated to enhance soil fertility (Felker, 1978). In Nepal, over 50 tree species can be found on farmlands. These trees often grow on terraces and are managed for their multiple outputs such as fodder, fuel, fruits, timber and fence posts, while assisting in soil stabilization (Fonzer \& Oberholzer, 1984). In arid parts of India and South America Prosopis spp. are intercropped with fodder and/or grain crops to provide fuelwood, agricultural implements and/or dry season fodder (Peck, 1984; Nair et al., 1984).

Again, in other parts of Asia, Africa and tropical America smallholders grow timber species such as Acrocarpus fraxinifolius, Albizzia spp., Alnus spp., Cedrela 
odorata, Cordia alliodora or Grevillea robusta as canopy trees over cash crops, food crops or pasture lands (Budowski, 1983; Poulsen, 1983; Peck, 1984). Among the most elaborate tree/crop combinations are the home-gardens characterized by a multi-layered mixture of a large number of food, fodder and timber-producing species grown in close association (Wilken, 1977; Wiersum, 1982; Fernandes et al., 1984).

All these and many other examples of traditional practices of combining trees with food crops, cash crops or livestock indicate the widespread utilization of trees for agricultural and livestock management by many rural people. These farm trees are often submitted to a silvicultural treatment which differs from the management practices of professional foresters. A very distinctive characteristic is the practice of regularly pruning, coppicing and pollarding. These practices are used to minimize potential land-use conflicts, to maximize the tree's production potential and to obtain regular yields of wood, fodder or mulch material over a long period of time (Poulsen, 1983; FAO, 1985).

\section{The scope for multipurpose trees}

As indicated by the above examples, in most cases where trees are incorporated in farming systems, local people favour multipurpose trees that provide multiple uses. Although theoretically virtually every species of tree or shrub can be used for more than one purpose the term 'multipurpose species' has been proposed to refer specifically to species that are deliberately used to provide products and services other than timber and pulpwood only and that are intentionally incorporated in multipurpose land-use systems (Burley \& von Carlowitz, 1984).

Potentially, there is a large number of species that can be classified as multipurpose. To date most attention has been focussed on a subset of this group of trees, i.e. the fast-growing nitrogen-fixing trees. These trees are often favoured for incorporation in farming systems because of their ability to fix atmospheric nitrogen biologically in a form that is usable to both the plant itself, to the soil (through plant litter) and to livestock (through fodder). This group of multipurpose trees includes mostly species from the Leguminosae family with additional Alnus and Casuarina species. Over 550 arboreal species have been confirmed to be able to form $\mathrm{N}$-fixing nodules (Halliday, 1984). Legumes are particularly widely used, as they offer a range of productive and protective services and as they combine rapid growth with good ecological adaptibility (National Academy of Sciences, 1979; Brewbaker et al., 1983; Nair et al., 1984).

Other arboreal species may also offer important multipurpose services. Some of these species, such as edible forest trees, fodder trees, bamboos, palms and rattan, are not yet widely familiar to foresters, but are receiving increasing attention for their potential to contribute to agricultural development (Okafor, 1977; Watson, 1982; Burley \& von Carlowitz, 1984).

Many of the multipurpose trees that are already being used by local farmers have been selected fron the indigenous flora. But in several tropical regions it can also be observed how farmers have planted exotic species on their fields. Sometimes the 
cultivation of these trees resulted from introductions made by the Forest Service. For instance, the spread of Azadirachta indica in the Sahel, introduced by foresters for roadside planting and woodlots, provides a striking example of the quick adoption of a multipurpose species which meets the needs of local farmers. And on Java (Indonesia), Calliandra calothyrsus was spontaneously adopted by local farmers after having been introduced in trial plantations of the Forest Service (FAO, 1985).

But many exotic farm trees have not been introduced by forest services, but by agricultural services. In the past, many agriculturists were interested in trees that could provide shade, mulching material and other services in cash crop plantations. The characteristics of these trees often fulfil the requirements of farmers better than the timber production characteristics of trees favoured by foresters. Examples of multipurpose trees that have been incorporated into indigenous smallholder farming systems after introduction into agricultural estates include Acacia mearnsii, Albizzia falcataria, Erythrina spp., Gliricidia sepium, Grevillea robusta and Leucaena leucocephala.

\section{Production potential of tree-enhanced fields}

As demonstrated in many existing farming systems that incorporate trees, the multiple roles of trees give these systems the potential to be more productive than farming systems that do not include trees. This increased productivity results from the improved production conditions for crops as well as from the production potential of trees themselves.

One of the major reasons for the increased awareness among foresters of the potential of farm trees is the growing recognition that in many tropical regions farm trees may provide anywhere from $60-90 \%$ of the aggregate local needs for wood. For example, in Kenya $47 \%$ of all wood consumed is produced on agricultural lands, $25 \%$ on range lands and only $28 \%$ in forests. And in both Pakistan and Java (Indonesia) an estimated $60 \%$ of all timber and $90 \%$ of all fuelwood is obtained outside forest reserves (van Gelder \& Wiersum 1983).

Another example of the important role played by farm trees in relation to wood production is provided by Cordia alliodora. This species is commonly incorporated in farm systems in tropical America. It is estimated to occur on an area of over one million hectares, where it produces between $5-20 \mathrm{~m}^{3} \mathrm{ha}^{-1}$ year-1. Although not recorded in any official forest statistics, this means that the species is the third largest plantation tree in the region (Budowski, 1983; Peck, 1984).

Growth data from farm trees are still scarce, but preliminary data indicate that the wood production potential of these trees is considerable (Table 2). Of course, production capacity is dependent upon many variables, including climate and soil conditions and the density of the tree stands. But the available data indicate often surprisingly high production figures compared with the normal production data from forests. Several factors contribute to this high production capacity. The soil quality of the farmers' fields is often better than that of lands commonly reserved for forests, while the trees may also profit from agricultural inputs such as fertilizers, irrigation and/or weed control. In a trial in Ruanda it was found that the pro- 
Table 2. Production capacity of farm trees.

Production capacity Source

$\left(\mathrm{m}^{3} \mathrm{ha}^{-1}\right.$ year-1)

Integrated trees and crops

Cordia alliodora over crops/pasture

Homegardens Java

(6) $10-15(20)$

$7-9$

$\begin{array}{ll}\text { Trees over upland crops, Java } & 3-5 \\ \text { Intercropped Leucaena hedgerows } & 1-3.5\end{array}$

Budowski, 1983

Intercropped Leucaena hedgerows

$0.7-2$

Van Gelder \& Wiersum, 1983

Van Gelder \& Wiersum, 1983

Torres, 1983b

Trees over upland crops, Kenya

Van Gelder \& Wiersum, 1983

Traditional multipurpose farmers' woodlots

Calliandra calothyrsus, Java 43-56

Leucaena leucocephala, Philippines 28-35

Gliricidia sepium, Philippines $\quad 23-40$

Sesbania grandiflora, Java 27-30

Van Gelder \& Wiersum, 1983

Van Gelder \& Wiersum, 1983

Van Gelder \& Wiersum, 1983

Van Gelder \& Wiersum, 1983

duction of wood and foliage of trees grown on agricultural lands was respectively four and three times higher than that of similar trees planted in a neighbouring woodlot with a similar soil (Behmel \& Zeuner, 1982). The fact that because of its open stand the trees produce much wood in branches rather than in the stem is not a serious disadvantage, as long as the wood is predominantly used for fuel.

The production capacity of farm trees is also positively influenced by the selection of appropriate fast-growing species and adaptive management techniques such as the coppicing and pollarding systems mentioned earlier. The positive effects of these factors are illustrated by the high yields of traditional multipurpose farmers' woodlots (see Table 2). The same trees are often also used in more open stands on agricultural fields.

Just as important as the production from trees is the possible improvement of agricultural production obtained on tree-enhanced fields. Although many observations indicate that properly managed farm trees may be the least-cost approach towards ensuring the sustained and even improved production of agricultural and forage crops, unfortunately few quantitative data are available to substantiate these claims or translate them into more detailed, site-specific information. However, some preliminary data from various Sahel countries indicate increases of 10 $50 \%$ in millet production on fields protected by scattered trees or shelterbelts (Felker, 1978; FAO, 1985). An on low-productivity sites the yields of maize cultivated between regularly pruned hedgerows of Leucaena leucocephala increased by 28-112\% (Torres, 1983b).

\section{Development opportunities for growing farm trees}

In many tropical regions farmers are experiencing a growing pressure on their resources because population growth, alterations in the socio-economic structure of society, agricultural and technological changes, and rising aspirations and expectations. These increasing pressures have caused a heavy demand for both land and 
tree resources. This has not only resulted in an unprecedented rate of uncontrolled deforestation, but often also in an overexploitation of trees outside the forest (Wiersum, 1984b). Although the process and magnitude of breakdown of traditional systems of farm tree management have not received as much attention as the process of deforestation, many observations indicate that the depletion of trees on agricultural lands may be as serious a problem as deforestation, especially in regard to the decreasing availability of wood products for the local population and the loss of agricultural production capacity.

Foresters in many tropical countries are thus faced with a growing need for tree products and services at the one hand and an accelerating loss of tree resources on the other hand. Several estimates indicate that in order to cover the forecasted deficits in tropical wood production at the end of this century, an equivalent of about 130 million hectares of new tree plantations is needed. An area fifteen times as large will potentially need to be newly forested to protect forests and soils from ecological or environmental deterioration (Wiersum, 1984b).

This task is so huge that it will only be possible to accomplish it if appropriate activities are undertaken by both professional forestry organizations and rural communities. Furthermore, it will be necessary not to restrict these activities to official forest reserves, but to extend tree planting to the whole of the rural landscape. Consequently, there is vast scope for programmes stimulating communities to properly incorporate compatible trees on farm lands so as to increase production of essential tree products as well as to improve land husbandry.

A wide variety of agroforestry techniques can be used in such programmes, e.g. managed or enriched fallows, hedgerow intercropping (alley cropping), shelterbelts, or various forms of multistorey intercropping such as growing multipurpose trees on crop fields and pastures, crops combinations with plantation species, or homegardens. Many efforts are at present under way to evaluate the precise advantages and limitations of these various techniques and to develop their full potentials. Much of this research is being directed towards the more systematic introduction of appropriate multipurpose species and the application of hedgerow intercropping (Torres, 1983b; Burley \& von Carlowitz, 1984; Nair et al., 1984).

For the development of programmes to stimulate tree farming three principles have been found to be of prime importance (Raintree, 1983; FAO, 1985). In the first place a programme should, whenever possible, concentrate its efforts on stimulating further adoption of still existing traditional or adaptive local land-use systems that incorporate trees, and on making incremental improvements in these systems. Such approaches, which are based on indigenous tree farming practices, will ensure that their effects and relative advantages are readily perceived by local farmers. Sometimes there may also be potential for introducing innovative farm tree management practices; but such innovations should only be used to supplement rather than to replace existing systems.

In the second place it is essential that farm tree growing schemes are based on the needs and potentials of individual farm units. Even within the same community, different households may have different tree-related needs, e.g. depending on patterns of land ownership, financial status and access to other production factors. For 
instance, some farmers may be interested in low-intensity management practices, which bring little direct financial gain, but which have substantial non-financial benefits, e.g. by increasing production of subsistence household needs. Other farmers may prefer higher inputs for tree management, which offer prospects for direct financial gain because of increases in commercial crop or wood production. Thus an approach is required in which farmers can choose between different options instead of presenting them with one standard technique.

In the third place, programmes should introduce multipurpose tree growing systems rather than concentrate on one output only. As indicated by all traditional systems, farmers expect multiple benefits from trees. They are rarely motivated to grow trees for one purpose (e.g. fuelwood) only, except in the case of easily marketed and highly priced cash crop commodities.

Thus, programmes for stimulating tree growing for agricultural and livestock development should be based on a farming system approach, in which the existing land-use situation is analysed, the different needs and available production factors of various population groups are assessed, and in which the multiple uses of trees for enhancing land-use are properly identified. To meet these needs, the International Council for Research on Agroforestry (ICRAF) has developed a 'Diagnostic and Design' methodology to guide planners in making good agroforestry designs (Raintree, 1983).

In conclusion, it is evident that the concepts and principles of using trees for agricultural and livestock development are fairly well documented and that the potential of incorporation trees in farming systems is widely demonstrated by indigenous practices. Although much further systematic research will be necessary to evaluate the exact scope for various tree farming systems under site-specific conditions, much experienced has already been gained during the last decade, and this can be applied in developing much needed programmes to stimulate more intensive management of farm trees.

\section{References}

Arnold, J. E. M., 1983. Economic considerations in agroforestry projects. Agroforestry Systems 1: 299-311.

Behmel, F. and I. Neumann, 1982. An example of agro-forestry in the African humid tropics. In: L. H. MacDonald (Ed.), Agroforestry in the African humid tropics. United Nations University, Tokyo, Japan, pp. 92-98.

Ben Salam, B. \& T. Van Nao, 1981. Fuelwood production in traditional farming systems. Unasylva 33 (131): 13-18.

Brewbaker, J. L., J. Halliday \& J. Lyman, 1983. Economically important nitrogen-fixing tree species. Nitrogen Fixing Tree Research Reports 1: 35-40.

Budowski, G., 1983. An attempt to quantify some current agroforestry practices in Costa Rica. In: P. A. Huxley (Ed.), Plant research and agroforestry. ICRAF, Nairobi, Kenya, pp. 43-60.

Burley, J. \& P. von Carlowitz, 1984. Multipurpose tree germplasm. Proceedings, recommendations and documents of a planning workshop to discuss international cooperation, ICRAF, Nairobi, Kenya.

Clarke, W. C., 1966. From extensive to intensive shifting cultivation: a succession from New Guinea. Ethnology 5: 347-359.

FAO, 1981. Forestry and rural development. FAO Forestry Paper No 26. FAO, Rome, Italy, 35 pp.

Neth. J. agric. Sci. 33 (1985) 
FAO, 1985. Tree growing by rural people. Draft report prepared for 7th FAO/SIDA Expert Consultation on Forestry for Local Community Development. FAO, Rome, Italy, $133 \mathrm{pp}$.

Felker, P., 1978. State of the art: Acacia albida as a complementary permanent intercrop with annual crops. Dept. of Soil \& Environmental Sciences, University of California, Riverside, California, USA.

Felker, P. \& S. Bandurski, 1979. Uses and potential uses of leguminous trees for minimal energy input agriculture. Economic Botany 33: 172-184.

Fernandes, E. C. M., A. Oktingati \& J. Maghembe, 1984. The Chagga home gardens: a multistoried agroforestry cropping system on Mt. Kilimanjaro (Northern Tanzania). Agroforestry Systems 2: 73-86.

Fonzer, P. F. \& E. Oberholzer, 1984. Use of multipurpose trees in hill farming systems in Western Nepal. Agroforestry Systems 2: 187-197.

Gelder, A. van \& K. F. Wiersum, 1983. (Wood production in tropical farming systems.) Landbouwkundig Tijdschrift 95(5): 27-30 (in Dutch).

Getahun, A., G. F. Wilson \& B. T. Kang, 1982. The role of trees in farming systems in the humid tropics. In: L. H. MacDonald (Ed.), Agroforestry in the African humid tropics. United Nations University, Tokyo, Japan, pp. 28-35.

Halliday, J., 1984. Register of nodulation reports for leguminous trees and other arboreal genera with nitrogen-fixing members. Nitrogen Fixing Tree Research Reports 2: 38-45.

Hammer, T., 1982. Reforestation and community development in the Sudan. Discussion Paper D-73M, Energy in developing countries series, Resources for the future, Washington, USA.

Nair, P. K. R., 1984. Soil productivity aspects of agroforestry. Science and practice of Agroforestry No 1. ICRAF, Nairobi, Kenya, 85 pp.

Nair, P. K. R., E. C. M. Fernandes \& P. N. Wamburger, 1984. Multipurpose leguminous trees and shrubs for agroforestry. Agroforestry Systems 2: 145-163.

National Academy of Sciences, 1979. Tropical legumes: resources for the future. NAS, Washington, USA.

Okafor, J. C., 1977. Development of forest tree crops for food supplies in Nigeria. Forest Ecology and Management 1:235-247.

ORSTOM, 1980. L'arbre en Afrique tropicale, la fonction et le signe. Cahiers ORSTOM, Série Sciences Humaines $17(3 / 4)$.

Peck, R. B., 1984. Traditional forestation strategies of local farmers in the tropics. In: K. F. Wiersum (Ed.), Strategies and designs for afforestation, reforestation and tree planting. Pudoc, Wageningen, Netherlands, pp. 206-216.

Pelzer, K. J., 1948. Pioneer settlement in the Asiatic tropics. American Geographic Society, New York, USA.

Poulsen, G., 1983. Using farm trees for fuelwood. Unasylva 35 (141):26-29.

Pullan, R. A., 1974. Farmed parkland in West Africa. Savanna 3: 119-151.

Raintree, J. B., 1983. Strategies for enhancing the adoptability of agroforestry innovations. Agroforestry Systems 1: 173-187.

Torres, F., 1983a. Role of woody perennials in animal agroforestry. Agroforestry Systems 1: 131-163.

Torres, F., 1983b. Potential contribution of Leucaena hedgerows intercropped with maize to the production of organic nitrogen and fuelwood in the lowland tropics. Agroforestry Systems 1: 323-333.

Watson, G. A., 1982. Tree crops in the lowland humid tropics - a time for a change. Outlook on Agriculture 11: 10-15.

Weinstock, J. M., 1983. Rattan: ecological balance in a Borneo rainforest swidden. Economic Botany 37: $58-68$.

Wiersum, K. F., 1982. Tree gardening and taungya on Java: examples of agroforestry techniques in the humid tropics. Agroforestry Systems 1: 53-70.

Wiersum, K. F., 1984a. Surface erosion under various tropical agroforestry systems. In: L. O. O'Loughlin \& A. J. Pearce (Eds.), Symposium on effects of forest land use on erosion and slope stability. Environmental \& Policy Institute, East-West Centre, Honolulu, Hawaii, USA, pp. 231-239.

Wiersum, K. F. (Ed.), 1984b. Strategies and designs for afforestation, reforestation and tree planting. Pudoc, Wageningen, Netherlands, $432 \mathrm{pp}$.

Wilken, G. C., 1977. Integrating forest and small-scale farm systems in Middle America. Forest Ecology and Management 1: 223-234. 